This copy is author's original pre-print version and may slightly differ from the official published version.

Full citation:

Harkonen, J., Belt, P., Mottonen, M., Kess, P. \& Haapasalo, H. (2009) 'Maturity of verification and validation in ICT companies', International Journal of Innovation and Learning, Vol. 6, No. 1, pp. 33-50.

\title{
Maturity of verification and validation in ICT companies
}

\section{Janne Harkonen*, Pekka Belt, Matti Mottonen, Pekka Kess \& Harri Haapasalo}

Department of Industrial Engineering and Management, University of Oulu, Finland, P.O. Box 4610, FI-90014 University of Oulu, Finland

E-mail: janne.harkonen@oulu.fi

E-mail: pekka.belt@oulu.fi

E-mail: matti.mottonen@oulu.fi

E-mail: pekka.kess@oulu.fi

E-mail: harri.haapasalo@oulu.fi

*Corresponding author

\begin{abstract}
This paper examines the maturity of Verification and Validation $(\mathrm{V} \& \mathrm{~V})$ activities in the different phases of new product development (NPD) chain. A CMMI-based Verification Validation Maturity Model (V2M2) is utilised for the analysis. In this study, the maturity of V\&V activities is analysed based on interviews conducted in major Scandinavian telecom companies. The study highlights how the maturity of $\mathrm{V} \& \mathrm{~V}$ in production is higher than in the earlier NPD phases. The overall maturity of V\&V activities is found to require significant improvement.
\end{abstract}

Keywords: verification; validation; testing; innovation; new product development; learning; maturity model. 


\section{Introduction}

Increasing product complexity, time-to-market pressures, changing requirements and the decrease in physical dimensions in electronics cause pressures for improving the efficiency of NPD processes. It has been argued that it is impossible to design and manufacture information and communications technology (ICT) products without defects (e.g. Woodward and Hennell, 2005). Therefore, assuring quality is a critical success factor (e.g. Hauser et al., 2007). Verification and validation activities have become increasingly important and have been estimated to take between 40 to 80 percent of hightechnology product development resources (e.g. Cartwright and Shepperd, 2000; Myers, 2004; Hailpern and Santhanam, 2002). Studies also indicate that in practice all companies have problems with their V\&V processes. (e.g. Andersson and Runeson, 2002; Runeson et al., 2003; Perttula 2007).

Verification and validation have typically not been considered sufficiently over the entire new product development chain. However, there are studies that consider improving V\&V within a single phase, or with a different perspective (e.g. Cheng et al., 2007; Engel and Last, 2007). In this study V\&V has been studied as an integral part of the NPD chain. This has been done by analysing V\&V activities in different NPD phases, namely: applied research, platform development, productisation, production and aftersales (Figure 1).

Figure 1 The phases of NPD chain

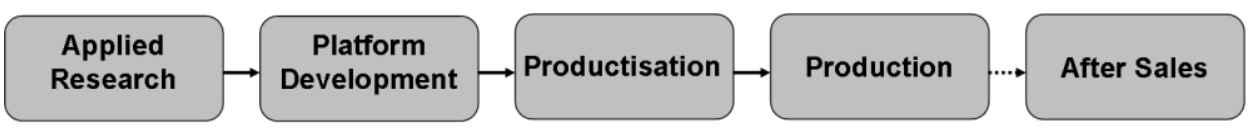

The terminology used in this paper includes, verification, validation and testing. The purpose of $\mathrm{V} \& \mathrm{~V}$, in a broad sense, is to supply information concerning the product design to the management, and other stakeholders for their decision-making (Perttula, 2007). V\&V can be divided into technical (verification) and customer-related (validation) elements (e.g. Mooz et al., 2003; Raghavendra and Subrahmanya, 2006; Suikki, 2007). The term 'testing' is used in this paper broadly as a synonym for verification and validation activities.

Maturity models are management tools that can also be used for assessing the performance of NPD chain (e.g. Tiku et al., 2007; Lee and Chang, 2006). However, companies often find maturity models somewhat abstract and difficult to perceive. A simple matrix was derived in this study to aid maturity analysis, and to ease the initial adoption of these models. This can help in sharing the knowledge over maturity models within companies.

This study utilises a $\mathrm{V} \& \mathrm{~V}$ specific maturity model, the verification validation maturity model (V2M2), for analysing the maturity of V\&V activities. However, as the very extensive original V2M2 is not directly applicable as a management tool, a simple matrix is constructed in this study for simplification, and to aid the analysis. The analysis is conducted for the different phases of the NPD chain. This paper presents a viewpoint on managing $V \& V$ activities throughout the chain, from applied research to after-sales. The empirical part of the paper describes the current status of managing V\&V activities across the NPD chain. The scope of the empirical study covers V\&V activities within the telecommunications industry.

The above-mentioned can be summarised in the following research questions: 
(RQ 1) What are the features of the Verification Validation Maturity Model (V2M2) that can be utilised to provide valuable information for management purposes?

(RQ 2) At what level of maturity are the V\&V activities in telecom companies?

This paper aims to derive a practical tool of the V2M2 model and applies it to interviews conducted in major Scandinavian telecom companies.

\section{Maturity of verification and validation}

One way of measuring process improvement is to utilise various types of maturity models. Processes cannot be improved before they are well understood, or it is very difficult (e.g. Daghfous, 2007). Examples of maturity models include, the Capability Maturity Model Integration (CMMI) (e.g. CMU/SEI, 2006; Lee and Chang, 2006), and its application specific variants such as the ones for testing and V\&V (e.g. Burnstein, 1996; Ham et al., 2001; Tiku et al., 2007; Farooq and Dumke, 2007). These frameworks have been considered as an approach for implementing a management viewpoint and have a great potential to be used as a guiding tool for managing $V \& V$ activities.

Whereas the maturity models enable assessing organisational maturity and allow identifying priorities for improvement, maximising their potential may require utilising some supporting techniques. Dayan and Evans (2006) see knowledge management (KM) and CMMI to be supporting, and dependent of, each other. KM and CMMI both take different approach to achieving competitive advantage, but may together make the organisation more efficient and effective. Also, according to Bellini and Lo Storto (2006), maturity models can effectively support and address knowledge management and learning. In addition, $\mathrm{KM}$ is an important systemic function for modern telecom organisation for improving organisational performance, however there are some deficiencies in understanding and guidance of KM within organisations (e.g. Wei et al. 2006; El-Korany, 2007; Lin and Kuo, 2007). A focus on processes is not enough to guarantee the effectiveness, but organisations must ensure they have functional measurement and management systems in place as well. (Tan and Hung, 2006).

Capability maturity models incorporate the essential elements of effective processes for diverse applications. As an example, the SW-CMM has become a de facto standard for assessing and improving software processes (e.g. Leung et al., 2007). The CMMI was developed to provide an enterprise-wide framework for improving and evaluating capability maturity across both software and systems engineering. The purpose of CMMI is to provide guidance for improving organisations' processes and their ability to manage important functions (e.g. Dayan and Evans 2006). However, CMMI does not cover all the activities that may be relevant for different practitioners, or explicitly address issues specific to their main functions (see e.g. McCaffery and Coleman, 2007; Beecham et al., 2005a; Beecham et al., 2005b). Testing and verification and validation have the need for their own application specific maturity models, such as Testing Maturity Model (TMM) (Burnstein, 1996) and Verification Validation Maturity Model (V2M2) (Ham et al., 2001; Jacobs and Trienekens, 2002).

Testing maturity model (TMM) was developed for the purpose of guiding the software testing process (Burnstein, 1996). However, TMM is seen to overlook the fact that improvement actions at higher levels cannot be carried out without considering the organisational aspects (e.g. Jacobs and Trienekens 2002).

Verification and validation maturity model (V2M2) (e.g. Ham et al., 2001; Jacobs and Trienekens, 2002; Farooq and Dumke, 2007) is a comprehensive model that has potential, because V2M2 is not geared towards any specific type of business, such as 
software engineering. Therefore, the verification validation maturity model allows a wider scope for $\mathrm{V} \& \mathrm{~V}$ process assessment. V2M2 model also has CMMI like structure, allowing better compatibility with any enterprise-wide maturity assessment interests. Additionally, V2M2 also takes the organisational aspects into consideration at higher levels.

The vast majority of industrial organisations spend considerable resources to promote product quality by using sub-optimal verification, validation and testing processes (e.g. Engel and Last, 2007). If a company improves its performance on the scale of a maturity model by one level, it can significantly reduce the share of development budget spent on fixing errors (e.g. Engel and Last, 2007; Houston and Keats, 1998). Therefore, it is vital to understand whether these models can provide improvement in practice.

In this paper, V2M2 maturity levels and process areas are combined into a single matrix outlining the core of the verification validation maturity model (Table 1). The information is combined into this matrix by utilising sources publicly available (Ham et al., 2001; Jacobs and Trienekens, 2002) to have a practical enough tool for assessing $\mathrm{V} \& \mathrm{~V}$ maturity. This is done as the maturity models have a tendency to seem virtually complicated, making them less attractive to be used as tools for analysis.

Practitioners have found the maturity models complicated and difficult to perceive, without taking substantial amount of time to obtain the required understanding (e.g. Whittaker and Voas, 2002; Maatta et al., 2007). In practice, this effort is only undertaken when forced to by customers or competition. Therefore, in this study, the most vital factors for starting maturity assessment with V2M2 model are combined into a matrix (Table 1) that provides a softer landing for the use of the actual model itself. The applicability of the matrix is tested in the empirical part, where it is used as an aid for analyses. 
Table 1 Maturity level matrix - based on Metric based Verification Validation Maturity Model (V2M2)

\begin{tabular}{|c|c|c|c|c|}
\hline $\begin{array}{l}\text { Level } 1 \\
\text { Initial }\end{array}$ & $\begin{array}{c}\text { Level } 2 \\
\text { Repeatable }\end{array}$ & $\begin{array}{l}\text { Level } 3 \\
\text { Defined }\end{array}$ & $\begin{array}{c}\text { Level } 4 \\
\text { Managed and Aligned }\end{array}$ & $\begin{array}{c}\text { Level } 5 \\
\text { Optimising }\end{array}$ \\
\hline $\begin{array}{l}\text { Main objective of } \mathbf{V} \& \mathbf{V}: \\
\text { To show in an ad-hoc way } \\
\text { that products work }\end{array}$ & $\begin{array}{c}\text { Main objective of V\&V: } \\
\text { Defect detection }\end{array}$ & $\begin{array}{c}\text { Main objective of } \mathbf{V} \& \mathbf{V}: \\
\text { Are based on the requirements }\end{array}$ & $\begin{array}{c}\text { Main objective of } \mathbf{V} \& \mathrm{~V}: \\
\text { To provide quantitative measures } \\
\text { to allow visibility for } \\
\text { management }\end{array}$ & $\begin{array}{l}\text { Main objective of } \mathbf{V} \& \mathbf{V}: \\
\text { To act as a total product } \\
\text { quality control, to result in } \\
\text { low risk products }\end{array}$ \\
\hline$N / A$ & $\begin{array}{c}\text { Purpose of the level: } \\
\text { The establishment of a basic } \\
\text { verification and validation } \\
\text { process } \\
\text { By the introduction of basic } \\
\text { practices, basic } V \& V \text { process } \\
\text { emerges }\end{array}$ & $\begin{array}{c}\text { Purpose of the level: } \\
\text { To further organise V\&V } \\
\text { and to embed it into the } \\
\text { development life-cycle } \\
\text { A defined and repeatable process } \\
\text { is in place, documented standards } \\
\text { and procedures }\end{array}$ & $\begin{array}{l}\text { Purpose of the level: } \\
\text { The establishment of } V \& V \text { as } \\
\text { a real quality measurement } \\
\text { By aligning the way-of-working } \\
\text { with other organisational } \\
\text { entities }\end{array}$ & $\begin{array}{c}\text { Purpose of the level: } \\
\text { To fine-tune and optimise } \\
\text { the V\&V process on a } \\
\text { continuous and structured } \\
\text { basis }\end{array}$ \\
\hline $\begin{array}{l}\mathrm{V} \& \mathrm{~V} \text { is finding and } \\
\text { correcting problems } \\
\text { Lack of tools, resources } \\
\text { and properly trained staff }\end{array}$ & $\begin{array}{l}\mathrm{V} \& \mathrm{~V} \text { is performed in a } \\
\text { systematic and planned way } \\
\text { Work products are } \\
\text { documented }\end{array}$ & $\begin{array}{l}\text { Activities start already at the } \\
\text { requirements phase } \\
\text { and continue } \\
\text { through the entire life-cycle }\end{array}$ & $\begin{array}{l}\text { Quantitative measurements, } \\
\text { statistical techniques and } \\
\text { methods control the process }\end{array}$ & $\begin{array}{c}\text { Costs, efficiency and } \\
\text { effectiveness are quantitatively } \\
\text { measured }\end{array}$ \\
\hline \multirow{2}{*}{$\begin{array}{l}\text { Lack of tools, resources } \\
\text { and properly trained staff }\end{array}$} & $\begin{array}{l}\text { Tests are conducted in a } \\
\text { dedicated } \mathrm{V} \& \mathrm{~V} \text { environment }\end{array}$ & $\begin{array}{c}\text { A } \vee \& V \text { organisation is in place } \\
\text { and testing is recognised as a } \\
\text { profession }\end{array}$ & & $\begin{array}{c}\text { Defect causal analysis and } \\
\text { defect prevention is a common } \\
\text { practice }\end{array}$ \\
\hline & & & & $\begin{array}{l}\text { The V\&V process is } \\
\text { continuously } \\
\text { monitored and improved }\end{array}$ \\
\hline Process areas: & $\begin{array}{l}\text { Process areas: } \\
\text { 1. V\&V policy and goals }\end{array}$ & $\begin{array}{l}\text { Process areas: } \\
\text { 1. Organisation embedding }\end{array}$ & $\begin{array}{l}\text { Process areas: } \\
\text { 1. Organisational alignment }\end{array}$ & $\begin{array}{l}\text { Process areas: } \\
\text { 1. Defect prevention }\end{array}$ \\
\hline None & $\begin{array}{l}\text { 2. } V \& V \text { project planning } \\
\text { 3. } V \& V \text { monitor and control } \\
\text { 4. } V \& V \text { design methodology } \\
\text { 5. } V \& V \text { environment }\end{array}$ & $\begin{array}{l}\text { 2. Training program } \\
\text { 3. } V \& V \text { life-cycle embedding } \\
\text { 4. Peer reviews }\end{array}$ & $\begin{array}{l}\text { 2. Quality measurement and } \\
\text { evaluation } \\
\text { 3. Quantitative process } \\
\text { management }\end{array}$ & $\begin{array}{l}\text { 2. Quality management } \\
\text { 3. Process optimisation }\end{array}$ \\
\hline
\end{tabular}


The levels in the V2M2 model are (1) initial, (2) repeatable, (3) defined, (4) managed and aligned, and (5) optimising. The matrix (Table 1) combines the factors that are most essential for an analysis, including the main objectives for each maturity level. The matrix also combines the explanations for the purposes of each level and lists the related process areas. The details of each process area, or any other deeper information, are not included in the matrix for simplicity. This is because the available materials regarding the V2M2 model provide perfect reference for understanding the deeper details, and table 1 was merely constructed to ease the initial conceptualisation and act as a tool to aid analyses.

To be at a certain maturity level requires, (1) conformance to some, but not necessarily all of the requirements at that level, and (2) conformance to all of the lower lever requirements. For example, activities cannot be said to be at level two, unless they are also in conformance with all the level one requirements. Nevertheless, activities can also have elements that conform to some of the higher level requirements. However, the non-conformance issues at lower levels must be addressed, and solved, before the activities can be said to be at a higher level.

\section{Empirical study}

\subsection{The research process}

The empirical study was conducted to obtain data for maturity analysis over the V\&V activities through the entire NPD chain. The studied phases included applied research, platform development, productisation, production and after-sales. The study concentrated in examining companies within the telecommunication industry. The empirical study consisted of twenty interviews, comprising a representation from different phases of the NPD chain. Interviews were conducted informally allowing the interviewees to explain and clarify the cases and topics as entities. Appendix A includes the interview form. All the individual interview results were analysed separately for each phase of the chain by using V2M2 model as a tool for analysis.

The companies that participated in the interviews can be divided into four categories (Figure 2): The first company type is the 'gadget' manufacturers that sell their products globally. These companies provide products for both business-to-customer and for business-to-business markets. The second type of companies can be seen as subcontractors, whose products are inputs into the first category. The third category is companies who provide comprehensive test services, including test equipment, knowhow and consulting services. The fourth category comprises of companies developing and selling test equipment, which can be used to solve testing problems in high technology product development, manufacturing and after-sales. Therefore, these interviews represent the $\mathrm{V} \& \mathrm{~V}$ activities in a versatile manner and provide understanding over managing diverse issues. 
Figure 2 Interviewed companies in the NPD chain

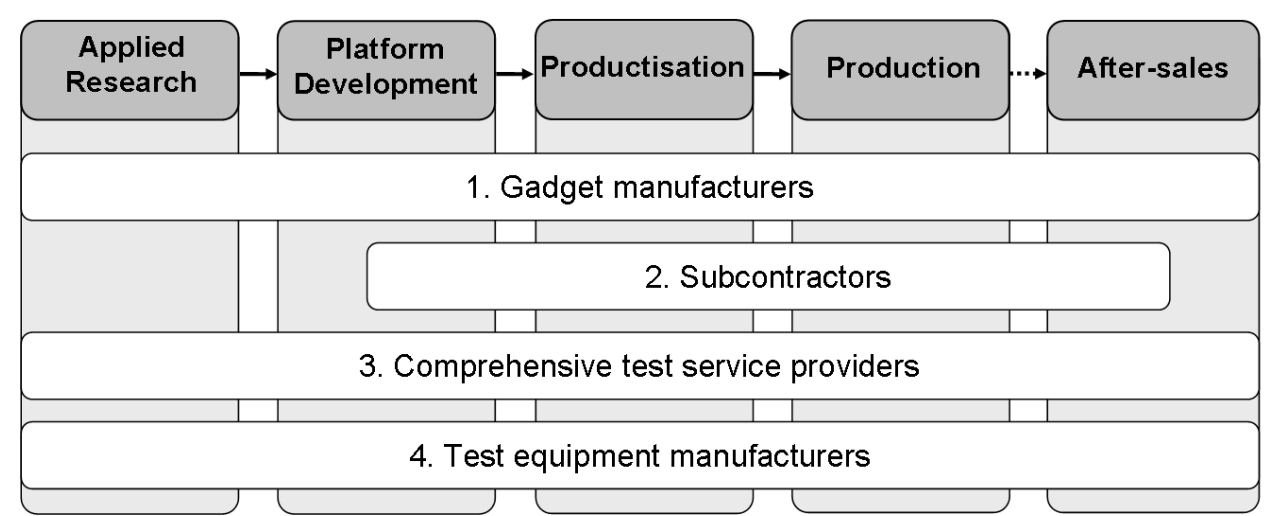

The participants interviewed were selected carefully on the basis of their professional background and expertise. Selected participants hold responsible positions in the field of $\mathrm{V} \& \mathrm{~V}$. The experience and the current interests ensured the high motivation among the participants and up-to-date knowledge with respect to the discussed topics. The total work experience of the interviewed is between 8 to 23 years, out of which they have spent a significant part with V\&V activities, but have also held other positions. The job titles of the respondents include: Quality Manager, Quality Controller, Competence Area Manager, Senior Test Manager, Product Development Manager, Director (R\&D), Engineering Manager, Manager (After-Sales), Group Manager, and Senior Developer. The selected participants were among the top-professionals in the field of $\mathrm{V} \& \mathrm{~V}$ and testing.

\subsection{Maturity analysis (V2M2)}

The interview material was analysed by using the matrix presented earlier (Table 1). The comments of the interviewees were analysed separately for each phase of product development (applied research, platform development, productisation, production and after-sales). The created matrix (Table 1) enabled the practical application of V2M2 model for the analysis. Deeper analysis was conducted by using the available material on the V2M2 model. The results obtained were then analysed as a whole, resulting in conclusions over the current state of $\mathrm{V} \& \mathrm{~V}$ activities in telecommunications industry.

Another issue that may influence the observed maturity is at which level the company's organisational issues will influence the conformance. This is, whether the NPD chain is observed as a whole, instead of viewing a single NPD phase as a sole 'organisation'. Examples of this consideration are, the level two process area one "V\&V policy and goals", and level four process area one "organisational alignment". It is clear that the level four process area one considers the company level issues. However, the way the organisational aspects of the "V\&V policy and goals" should be interpreted is not clear (see the process area details e.g. Jacobs and Trienekens, 2002). In this study, we have assumed that the company level organisational aspects are not to be considered before level four, but have brought this issue up in the later analyses for each NPD phase.

Tables 2-6 present extracted interviewee comments, which reflect the way the interviewees view V\&V activities in the discussed NPD phases. The interview data was the base on which the more in depth analysis was conducted. However, the tables do not directly indicate which elements are missing of conformance towards different maturity 
levels. Also, the obtained maturity levels may be slightly different for single companies, when analysed as single entities, and compared to the results presented later. This study has intentionally included the entire chain that has influence on the emergence of products to the markets.

\subsubsection{Applied Research}

The interviewee comments, supporting, or being against conformance towards each maturity level are presented in table 2. When comparing the comments of the interviewees against the V2M2 model (e.g. table 1), it can be concluded that the interviewee comments fully support the $\mathrm{V} \& \mathrm{~V}$ activities to level one requirements, but only partially conforming to level two. Nevertheless, some issues were brought up that do contribute towards higher level requirements, yet it was evident that $\mathrm{V} \& \mathrm{~V}$ in this phase is at most at level two. Common view across the organisation was not fully reflected as per level two process area one "V\&V policy and goals" (see process area details e.g. Jacobs and Trienekens, 2002), and therefore the maturity of this phase cannot be any higher than level two. In addition, the goals of $\mathrm{V} \& \mathrm{~V}$ in this phase are not clear due to uncertainty as per level two process area one "V\&V policy and goals". Our conclusion on the level of $\mathrm{V} \& \mathrm{~V}$ maturity on applied research is based on the interviewee comments (see Table 2), and on a more in depth analysis of the process areas. The maturity of verification and validation activities in applied research, within the telecommunications industry, is at level two.

Table 2 Extracted interviewee comments for $\mathrm{V} \& \mathrm{~V}$ in applied research

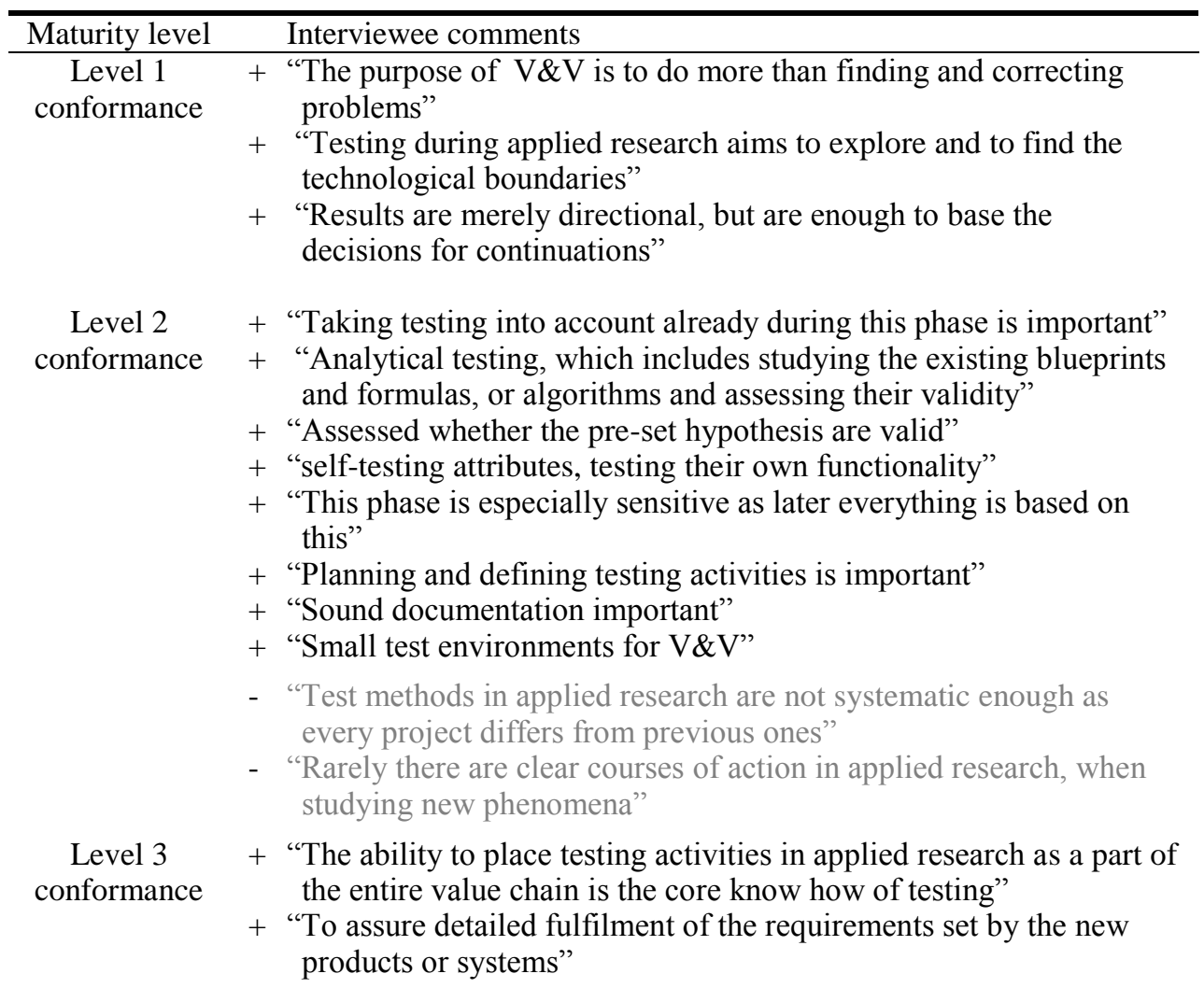


+ "Testing activities should be started as early as possible"

+ "It is important to consider and understand the role of V\&V throughout the product life-cycle

Level $4+$ "Clear enough and measurable parameters with defined

conformance requirements serve testing in the following phases the best"

+ "Co-operation with measuring equipment manufacturers and with test software houses is important"

Level 5 N/A conformance

$[(+)=$ supports conformance $(-)=$ against conformance $]$

\subsubsection{Platform development}

The interviewee comments over the conformance issues obtained are presented in table 3 . This phase is fully conforming to level one requirements, and clearly is at maturity level two. Nevertheless, platform development is not fully conforming to the level two requirements. Some issues also contribute towards higher levels than two. Common view across the organisation was not fully reflected as per level two process area one "V\&V policy and goals". Also, it can be seen how the goals of V\&V in this phase are not clear due to uncertainty as per level two process area one "V\&V policy and goals" (see process area details e.g. Jacobs and Trienekens, 2002). The maturity of verification and validation activities in platform development phase is at level two.

Table 3 Extracted interviewee comments for V\&V in platform development (early product development)

\begin{tabular}{|c|c|c|}
\hline Maturity level & & Interviewee comments \\
\hline $\begin{array}{c}\text { Level } 1 \\
\text { conformance }\end{array}$ & + & $\begin{array}{l}\text { "Testing at the early product development is mainly exploring } \\
\text { the limitations, a learning curve" } \\
\text { "The technical skills and knowledge required for testing are } \\
\text { available" }\end{array}$ \\
\hline \multirow[t]{7}{*}{$\begin{array}{c}\text { Level } 2 \\
\text { conformance }\end{array}$} & + & $\begin{array}{l}\text { "Testing in platform development starts from making a test } \\
\text { plan" }\end{array}$ \\
\hline & + & $\begin{array}{l}\text { "Explicit plans of what should be tested and of the required test } \\
\text { environments are desired in this phase" }\end{array}$ \\
\hline & + & $\begin{array}{l}\text { "Testing activities vary from creating test solutions for mobile } \\
\text { device functionalities, such as tracking function, for which } \\
\text { test environments are developed" }\end{array}$ \\
\hline & + & $\begin{array}{l}\text { "It is important to prioritise what is really important, as there is } \\
\text { infinite possibilities for faults, many of which will never be } \\
\text { faced by customers" }\end{array}$ \\
\hline & + & $\begin{array}{l}\text { "The aim is to rule out the errors the end-user can become } \\
\text { aware of during the intended use" }\end{array}$ \\
\hline & + & $\begin{array}{l}\text { "Planning testing activities and defining the focus is vital, as } \\
\text { once this has been well documented, the same subjects do not } \\
\text { need to be tested repeatedly in the future phases" }\end{array}$ \\
\hline & - & $\begin{array}{l}\text { "Defining testing in this phase is difficult as there are multiple } \\
\text { possibilities of using the subject in later phases" } \\
\text { "Too often testing is conducted by the inexperienced } \\
\text { employees" }\end{array}$ \\
\hline
\end{tabular}


Level $3+$ "Testing in the hierarchy of early product development is conformance verifying the requirements specifications and reviews, which are then utilised to create product specifications"

$+\quad$ "The core know-how in this phase is testing against technological solutions and requirements"

+ "DFT is an example of a technique to anticipate the test activities, later phases in mind"

$+\quad$ "This is fundamental work that everything is based on later, as all the faults and errors remaining after this phase will accumulate to the final product"

- "Testing should be viewed more as a natural element of the product creation process"

- $\quad$ "Tight schedules cause some prioritisation, making some of the internal wishes secondary"

Level $4+$ "Testing in this phase is quality assurance, where testing and conformance the faults, or error correction, are visible as error costs"

$+\quad$ "Co-operation is important to be able to specify and develop test methods and equipment"

Level 5

N/A

conformance

$[(+)=$ supports conformance $(-)=$ against conformance $]$

\subsubsection{Productisation}

Table 4 presents the interviewee comments for $\mathrm{V} \& \mathrm{~V}$ in productisation. It can be clearly seen how the interviewee comments indicate full conformance to level one, when compared to the verification validation maturity model. Productisation is fully conforming also with the level two requirements and process areas. However, V\&V activities in productisation are only partially conforming to level three requirements, and cannot therefore be at a higher maturity level. Nevertheless, some evidence does contribute towards higher levels. As examples of non-conformance with all the level three requirements can be seen the "organisation embedding" and "V\&V life-cycle embedding" (see Table 1) not fully being reflected as per level three process areas one and three (see process area details e.g. Jacobs and Trienekens, 2002). Therefore, the maturity of verification and validation activities in productisation is at level three.

Table 4 Extracted interviewee comments for $\mathrm{V} \& \mathrm{~V}$ in productisation (late product development)

\begin{tabular}{cc}
\hline Maturity level & Interviewee comments \\
\hline $\begin{array}{c}\text { Level } 1 \\
\text { conformance }\end{array}$ & + "Testing in this phase is quite straightforward set of activities, but the \\
Level 2 & actual challenge is with the systematic scrutinising of the product" \\
conformance & "One needs to understand the development history of the product in \\
this phase, so that the testing activities can be planned in a & meaningful way" \\
+ & "Once faults, or errors, are discovered, the people involved in testing \\
must be capable of analysing their causes and making the required \\
changes" \\
+ \\
+ "It is essential to know how the test results are obtained" \\
+ "Testing in this phase is expected to find faults and errors on the \\
product being developed, and to provide information on how the
\end{tabular}


specifications can be filled"

+ "The output of this phase is proficiently verified product, including the test equipment and required software, which is all ready to be moved into production"

Level $3+$ "Testing activities in the following phase, production, are also conformance considered in this phase, as it is important to understand which tests are to be covered before releasing the product to the markets"

+ "There are norms against which the tests will be conducted to have them approved"

+ "Any changes in this phase, even small ones, will cause the product having to be tested thoroughly from scratch, to make sure it is functioning as previously defined"

+ "The purpose of testing in productisation is to assure that the product fulfils the specifications set in the applied research"

- "It is impossible to conduct product development project in an ideal way from the testing viewpoint"

Level $4+$ "From the viewpoint of quality, testing activities and correcting the conformance found errors are error costs"

+ "One of the aims of testing is to minimise the expenses, while keeping the coming production process in mind"

- "Internal functions do not always understand the requirements of the internal customer well enough, to accommodate the next phase in the process"

- "Different activities should be directed more based on the requirements set by testing activities"

Level 5

N/A conformance

$[(+)=$ supports conformance $(-)=$ against conformance $]$

\subsubsection{Production}

The evidence in the form of extracted interviewee comments is presented in Table 5. Verification and validation in production can be seen to clearly conform to the level one and two requirements, when production phase is observed as a separate entity. Should the entire chain be observed as a single assessment, one should pay special attention on how the common view across the organisation is reflected as per level two process area one "V\&V policy and goals". V\&V activities in production are only partially conforming to the level three requirements. However, production phase has evidence indicating conformance to higher levels, which shows an orientation towards even higher levels. No clear non-conformance issues were discovered directly from the interviewee comments for any of the levels. However, a closer analysis clearly indicates how all the requirements are fully conforming to, only until level three, but not beyond. The interviews indicate how "organisation embedding" and "V\&V life-cycle embedding" (see table 1) are not fully reflected as per level three process areas one and three (see process area details e.g. Jacobs and Trienekens, 2002). Should the interviewee comments be compared to higher levels, it can be seen how organisational alignment is not fully reflected as per level four process area one, or the process area three. Also, "quantitative process management" with regards to $\mathrm{V} \& \mathrm{~V}$ is insufficiently covered. Additionally, if 'integrated and standard $\mathrm{V} \& \mathrm{~V}$ processes would be defined to deploy the process, and to 
coordinate and facilitate the organisation's V\&V activities', as per “organisation embedding", level three process area one content, production phase would be very close to being at level four. However, the maturity of $\mathrm{V} \& \mathrm{~V}$ production is at level three.

Table 5 Extracted interviewee comments for $\mathrm{V} \& \mathrm{~V}$ in production

\begin{tabular}{|c|c|c|}
\hline Maturity level & & Interviewee comments \\
\hline \multirow[t]{2}{*}{$\begin{array}{c}\text { Level } 1 \\
\text { conformance }\end{array}$} & + & $\begin{array}{l}\text { "Normally the tests a product must pass have been considered } \\
\text { already during product development" }\end{array}$ \\
\hline & + & $\begin{array}{l}\text { "Testing in this phase is assuring the compatibility and the intended } \\
\text { functioning of the product"." }\end{array}$ \\
\hline \multirow[t]{2}{*}{$\begin{array}{l}\text { Level } 2 \\
\text { conformance }\end{array}$} & + & $\begin{array}{l}\text { "The role of production is to duplicate the designed product. } \\
\text { Therefore, there should not be any other forms of testing than } \\
\text { testing for the errors caused by the production process itself" }\end{array}$ \\
\hline & + & $\begin{array}{l}\text { "All the results obtained in testing are recorded into a database with } \\
\text { the details of any repair actions" }\end{array}$ \\
\hline \multirow[t]{4}{*}{$\begin{array}{l}\text { Level } 3 \\
\text { conformance }\end{array}$} & + & $\begin{array}{l}\text { "The interaction between testing activities in production and R\&D is } \\
\text { strong" }\end{array}$ \\
\hline & + & $\begin{array}{l}\text { "The source information for testing in production includes the } \\
\text { information on how testing should be performed" }\end{array}$ \\
\hline & + & $\begin{array}{l}\text { "Sufficient planning of the testing activities prior to production is of } \\
\text { paramount importance to be able to detect any anomalities as early } \\
\text { as possible" }\end{array}$ \\
\hline & - & $\begin{array}{l}\text { "In some instances, there is overlapping with previous test phases, } \\
\text { causing unnecessary repeat of tests in production" }\end{array}$ \\
\hline \multirow[t]{4}{*}{$\begin{array}{l}\text { Level } 4 \\
\text { conformance }\end{array}$} & + & $\begin{array}{l}\text { "Testing in this phase is tangible in the form of different test } \\
\text { equipment, which are utilised to measure the quality of the } \\
\text { product" }\end{array}$ \\
\hline & + & $\begin{array}{l}\text { "Statistical methods, such as SPC (statistical process control), are } \\
\text { utilised to analyse the measured results. The results are observed } \\
\text { for possible trends, which may predict possible errors" }\end{array}$ \\
\hline & + & $\begin{array}{l}\text { "Separate test equipment is compared to each other's results, so that } \\
\text { any test equipment based errors will be detected" }\end{array}$ \\
\hline & + & $\begin{array}{l}\text { "Automatic alarms give warnings, when the set values are being } \\
\text { exceeded" }\end{array}$ \\
\hline \multirow[t]{2}{*}{$\begin{array}{l}\text { Level } 5 \\
\text { conformance }\end{array}$} & + & $\begin{array}{l}\text { "Testing activities in this phase are optimising and verifying that the } \\
\text { product, or assuring a part of the product is functional" }\end{array}$ \\
\hline & + & $\begin{array}{l}\text { "Once the production is up and running, and the most essential tests } \\
\text { have been recognised, testing activities can be optimised" }\end{array}$ \\
\hline
\end{tabular}

\subsubsection{After-sales}

Table 6 presents the evidence extracted from the interviewee comments for the after-sales phase. After-sales can be seen to fully conform to level one requirements, but only partially to conform to level two requirements. A noteworthy factor is that no evidence was found that would indicate contribution towards any higher levels than two. It can be clearly seen how common view across the organisation is not fully reflected as per level two process area one "V\&V policy and goals" (see process area details e.g. Jacobs and Trienekens, 2002). In addition, no dedicated V\&V environment for after-sales only are 
indicated through the evidence. The maturity of $\mathrm{V} \& \mathrm{~V}$ activities in after-sales functions is at level two.

Table 6 Extracted interviewee comments for V\&V in after-sales

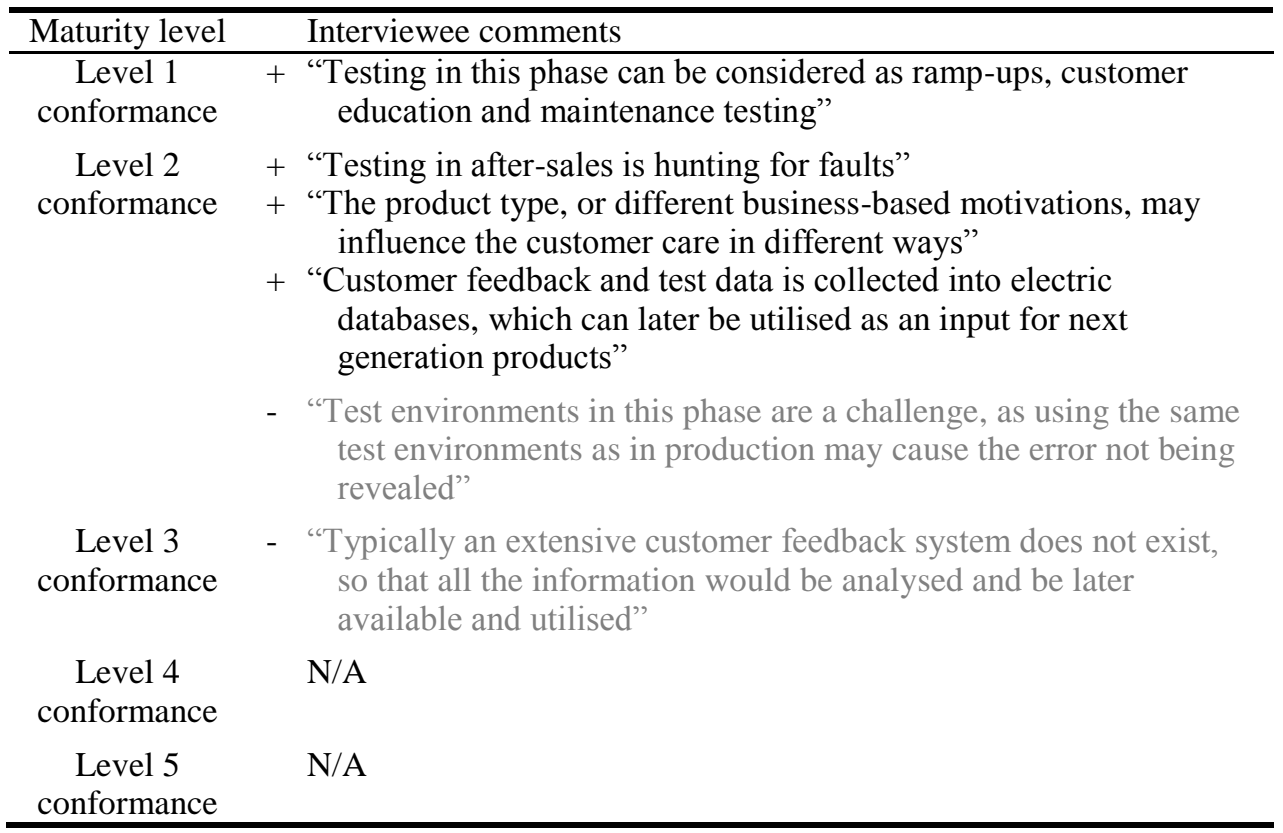

$[(+)=$ supports conformance $(-)=$ against conformance $]$

\subsubsection{Summary of the phase-wise analysis}

Figure 3 presents the current levels of maturity for V\&V activities in each NPD phase. Verification and validation in applied research, platform development and after-sales services are all at level two maturities, according to the conducted analysis. Productisation and production phases indicate clearly higher level three maturity for $\mathrm{V} \& \mathrm{~V}$ activities. However, the analysis undoubtedly revealed that the V\&V activities in production are at the highest level, even if the maturity 'classification' according to V2M2 model is the same for productisation phase. 
Figure 3. Current maturity levels in each NPD phase of telecommunications industry

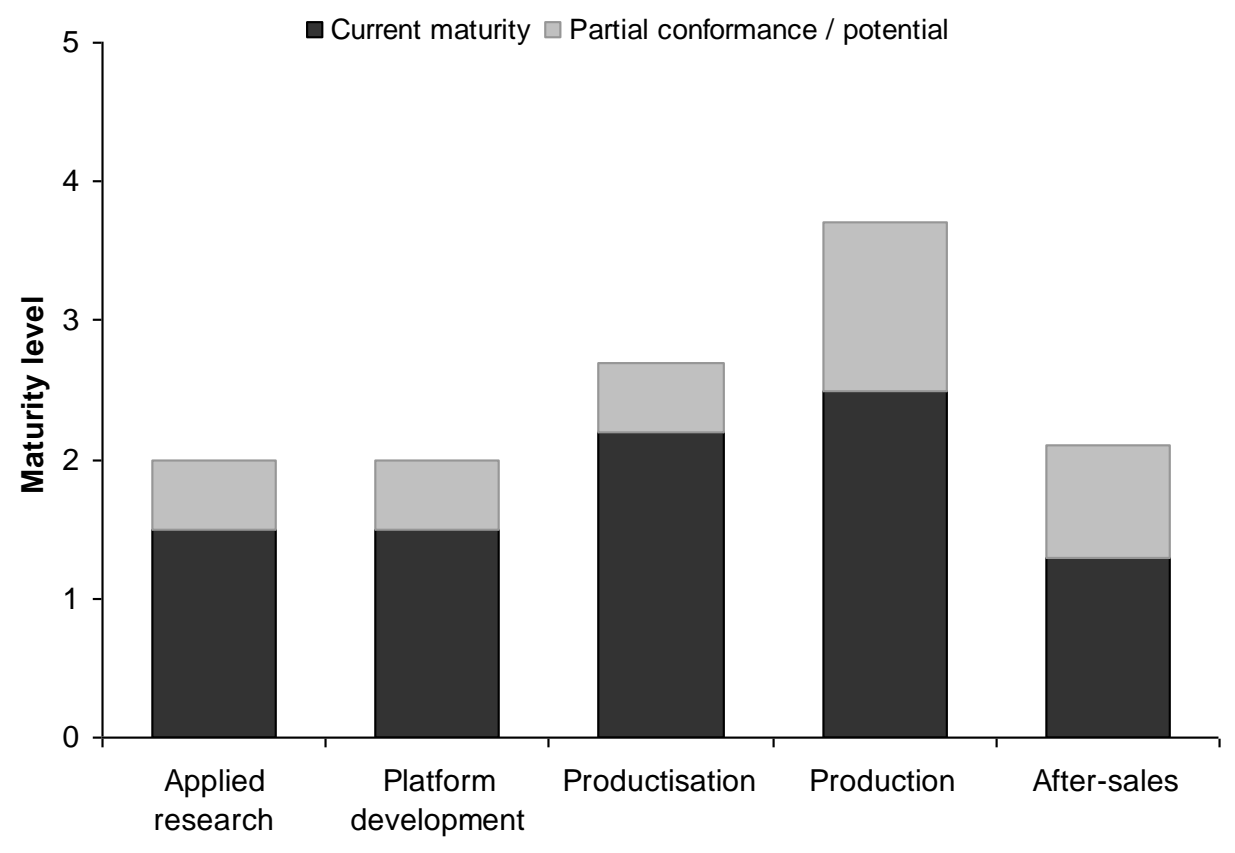

Product development phases

The congruent areas in Figure 3 that fill the maturity levels completely indicate which level requirements the particular NPD phase fully conforms to. However, the congruent area filling a maturity level only partially indicates that the V\&V in that particular NPD phase is at that level of maturity according to the analysis. For example, if the congruent area is between levels one and two, $\mathrm{V} \& \mathrm{~V}$ in that phase is at level two maturity. The shaded, light grey, areas indicate how the phase is not conforming to all the requirements at a level, but also indicate if there is strong potential for improvement.

The greatest dilemma for the entire analysis was set by the first process area of maturity level two; "V\&V policy and goals" (see details e.g. Jacobs and Trienekens, 2002). If this process area was taken literally, "V\&V policy is necessary to attain a common view on $\mathrm{V} \& \mathrm{~V}$ between all relevant stakeholders within an organisation", none of the phases studied would have a higher level of maturity than two. Only if every single phase is studied as an entity of its own right, the maturity level can be seen to be higher than two. This is when the above statement is taken literally to indicate the company level 'organisation'. The other similar 'obstacles' for higher maturity levels can be found on levels 3 and 4, where the first process area in both relate to organisational aspects in the same manner as above mentioned ("organisation embedding and organisational alignment"). One possibility is to see each NPD phase as a separate 'organisation' until maturity level four 'organisational embedding'

\section{Managerial implications}

Verification and validation activities have become a very important factor for new product development in ICT. However, V\&V have been managed sub-optimally in the 
NPD chain, and the overall coordination has been deficient. Also, the emphasis of these activities has traditionally been too late in the development chain (e.g. Blackburn et al., 1996; Pinheiro, 2003).

Maturity models can help in understanding V\&V through the NPD process, and the prevailing practices better. These models also provide the management with tangible indicators for their process improvement efforts. The matrix developed in this study is a concrete way to share knowledge more easily within an organisation, over an issue that is challenging to perceive initially.

Potential reason for $V \& V$ activities being managed sub-optimally is the fact that the maturity of these activities has not been high enough throughout the NPD chain. It is not possible to consider V\&V comprehensively before the "organisational alignment" is taken care of and the activities are at the maturity level four of V2M2. Once the V\&V maturity is high enough in all the phases, the processes can be dealt with organisationwide. Only this will truly allow the early consideration of $\mathrm{V} \& \mathrm{~V}$ activities, and remove overlapping.

Maturity level being high means that an organisation is capable of reacting rapidly to external changes. This type of agility has been brought up strongly, especially with software related projects. At the level three, V2M2 model has the purpose of embedding $\mathrm{V} \& \mathrm{~V}$ into the development chain, which will help with the capability to react. However, this cannot be accomplished fully unless the $\mathrm{V} \& \mathrm{~V}$ activities are at least at level four maturity. This also includes developing $\mathrm{V} \& \mathrm{~V}$ related competencies continuously.

\section{Conclusions}

The large scale of verification and validation activities requires a comprehensive understanding. Estimating the maturity of the $\mathrm{V} \& \mathrm{~V}$ processes is a necessity to be able to develop the NPD phases in a well-balanced manner. Maturity models are generally seen as good and effective tools for continuous process improvement. The CMMI-based $\mathrm{V} 2 \mathrm{M} 2$ model being a $\mathrm{V} \& \mathrm{~V}$ specific maturity model is a potential tool for developing $\mathrm{V} \& \mathrm{~V}$ processes. However, the practitioners have experienced these models, including V2M2, somewhat abstract and difficult to perceive. To alleviate this difficulty, a simple matrix was derived in this study to enable a quick initial analysis (see Table 1). The main benefit of this created matrix is that it enables a straightforward start of maturity evaluations. The matrix also allows discussion within a company and sharing the knowledge promptly over maturity models and acts as a first step for a deeper analysis. The matrix was tested for analysing data and was found suitable for a quick ballpark estimate on the state of $\mathrm{V} \& \mathrm{~V}$ process maturity. A deeper analysis was then conducted by utilising the available V2M2 material. (rq1)

Previous studies have indicated how the V\&V activities in the ICT industry have deficiencies due to not managing $\mathrm{V} \& \mathrm{~V}$ in an ideal manner (e.g. Runeson et at., 2003; Andersson and Runeson, 2002). In this study, the maturity of $\mathrm{V} \& \mathrm{~V}$ activities was analysed in companies involved in telecommunications. Each phase of the NPD chain was first studied separately, after which the entire chain was considered. The V\&V maturity was found to be the highest in production. The maturity of V\&V activities in the other NPD phases are lower and therefore are preventing production from rising higher. This study thus confirms the findings of previous studies, indicating late emphasis of $\mathrm{V} \& \mathrm{~V}$. Reaching a higher maturity level requires the entire chain to improve their $\mathrm{V} \& \mathrm{~V}$ maturity. (rq2)

The influence of maturity of $\mathrm{V} \& \mathrm{~V}$ activities requires further research. This is, for example, how the overall maturity of the company affects the maturity of $\mathrm{V} \& \mathrm{~V}$. 
Knowledge management consideration is also an interesting viewpoint as an addition to maturity models, thus is worth further research.

The number of interviews was not especially extensive, thus by having a wider set of organisations to be reviewed, the obtained results would have yielded a somewhat different analysis of the maturity of $\mathrm{V} \& \mathrm{~V}$. This study, however, strengthens the view on $\mathrm{V} \& \mathrm{~V}$ maturity and demonstrates how it is worthwhile to dissect it in a phase-wise manner.

\section{References}

Andersson, C. and Runeson, P. (2002) 'Verification and validation in industry - a qualitative survey on the state of practice', Proceedings, Empirical Software Engineering, pp. 37-47.

Beecham, S., Hall, T., Britton, C., Cottee, M. and Rainer, A. (2005a) 'Using an expert panel to validate a requirements process improvement model', The Journal of Systems and Software, Vol. 76, No. 3, pp. 251-275.

Beecham., S., Hall, T. and Rainer, A. (2005b) ' Defining a requirements process improvement model', Software Quality Journal, Vol. 13, No. 3, pp. 247-279.

Bellini, E. and Lo Storto, C (2006) 'The impact of software capability maturity model on knowledge management and organisational learning: empirical findings and useful insights', International Journal of Information Systems and Change Management, Vol. 1, No. 4, pp. 339-373.

Blackburn, J., Hoedemaker, G. and Van Wassenhove, L. (1996) 'Concurrent software engineering: prospects and pitfalls', Transactions on Engineering Management, Vol. 43, No. 2, pp. 179188.

Burnstein, I. (1996) 'Developing a Testing Maturity Model', Illinois Institute of Technology.

Cartwright, M. and Shepperd, M. (2000) 'An empirical investigation of an object-oriented software system', Software Engineering, Vol. 26, No. 8, pp. 786-796.

Cheng, S-R., Hsu, B-M. and Shu, M-H. (2007) 'Fuzzy testing and selecting better processes performance', Industrial Management and Data Systems, Vol. 107, No.6, pp. 862-881.

CMU/SEI (2006) 'CMMI® for Development', Version 1.2', Carnegie Mellon University, Software Engineering Institute.

Daghfous, A. (2007) 'Absorptive capacity and innovative enterprise systems: a two-level framework', International Journal of Innovation and Learning, Vol. 4, No. 1, pp. 60-73.

Dayan, R. and Evans, S. (2006) ' KM your way to CMMI', Journal of Knowledge Management', Vol. 10, No. 1, pp. 69-80.

El-Korany, A. (2007) 'A knowledge management application in enterprises', Int. Journal of Management and Enterprise Development, Vol. 4, No.6, pp. 693-702.

Engel, A. and Last, M. (2007) 'Modeling software testing costs and risks using fuzzy logic paradigm', The Journal of Systems and Software, Vol. 80, No. 6, pp. 817-835.

Farooq, A. and Dumke, R.R. (2007) 'Research directions in verification \& validation process improvement', ACM SIGSOFT Software Engineering Notes, Vol. 32, No. 4, article no. 3.

Hailpern, B. and Santhanam, P. (2002) 'Software debugging, testing, and verification', IBM Systems Journal, Vol. 41, No. 1, pp. 4-12.

Ham, M., Jacobs, J., Swinkels, R., and Van Veenendaal, E. (2001). 'Metric Based Testing Maturity Model Framework v1.1', [Available online], <http://mitwww.tm.tue.nl/research/v2m2/>, Read 22.11.2004.

Hauser, K., Pratt, J.A. and Mills, R.J. (2007) 'Integrating a problem-based approach for systems analysis and design curriculum: a 'bug hunt", International Journal of Innovation and Learning, Vol. 4, No. 6, pp. 571-586. 
Houston, D. and Keats, J.B. (1998) 'Cost of software quality: a means of promoting software process improvement', Quality engineering, Vol. 10, No. 3, pp. 563-573.

Jacobs, J. and Trienekens, J. (2002) 'Towards a Metrics Based Verification and Validation Maturity Model' Lecture Notes in Computer Science, Vol. 2434, pp. 133-148.

Lee, M-C. and Chang, T. (2006) 'Applying TQM, CMM and ISO 9001 in Knowledge Management for software development process improvement', International Journal of Services and Standards, Vol. 2, No. 1, pp. 101-115.

Leung, H.K.N., Liao, L. and Qu, Y. (2007) 'Automated support of software quality improvement', International Journal of Quality \& Reliability Management, Vol. 24, No. 3, pp. 230-243.

Lin, C-Y. and Kuo, T-H. (2007) 'The mediate effect of learning and knowledge on organizational performance', Industrial Management and Data Systems, Vol. 107, No. 7, pp.1066-1083.

Maatta, J., Harkonen, J., Jokinen, T., Mottonen, M., Belt, P., Muhos, M. and Haapasalo, H. (2007) 'How to enhance the efficiency of testing - Management viewpoint?', Journal of Engineering and Technology Management (Accepted - forthcoming).

McCaffery, F. and Coleman, G. (2007) 'Developing a configuration management capability model for the medical device industry', Int. Journal of Information Systems and Change Management, Vol. 2, No.2, pp. 139-154.

Mooz, H., Forsberg, K., Cotterman, H. (2003) 'Communicating project management: the integrated vocabulary of project management and systems engineering', Wiley, pp. 360

Myers, G.J. (2004) 'The Art of Software Testing', second edition, Wiley, pp. 256.

Perttula, A. (2007) 'Challenges and Improvements of Verification and Validation Activities in High Volume Electronics Product Development', PhD dissertation, Tampere University of Technology, Finland. Publication 650

Pinheiro, F. (2003) 'Requirements honesty', Requirements Engineering, Vol. 8, No. 3, pp.183-192.

Raghavendra, N.V. and Subrahmanya, M.H.B. (2006) 'Development of a measure for technological capability in small firms', International Journal of Innovation and Learning, Vol. 3, No. 1, pp. 31-44.

Runeson, P., Andersson, C. and Host, M. (2003) 'Test processes in software product evolution - a qualitative survey on the state of practice', Journal of Software Maintenance and Evolution, Vol. 15, No. 1, pp. 41-59.

Suikki, R. (2007) 'Changing Business Environment-Effects Of Continuous Innovations and Disruptive Technologies', PhD Dissertation, University of Oulu, ISBN 978-951-42-8342-0.

Tan, B. and Hung, H-C. (2006) 'A knowledge management system introduction model for smalland medium-sized enterprises', Int. Journal of Management and Enterprise Development, Vol. 3, No. 1/2, pp. 53-69.

Tiku, S., Azarian, M. and Pecht, M. (2007) 'Using a reliability capability maturity model to benchmark electronics companies', International Journal of Quality \& Reliability Management, Vol. 24, No. 5, pp.547-563.

Wei, C.C., Choy, C.S. and Yeow, P.H.P (2006) 'KM implementation in Malaysian telecommunication industry: An empirical analysis', Industrial Management and Data Systems, Vol. 106, No. 8, pp. 1112-1132.

Whittaker J. A. and Voas J. M. (2002) '50 years of software: key principles for quality', IT Professional, Vol. 4, No. 6, pp. 28-35.

Woodward, M.R. and Hennell, M.A. (2005) 'Strategic Benefits of Software Test Management: a Case Study', Journal of Engineering and Technology Management, Volume 22, Issues1-2, p. 113-140. 


\section{APPENDIX A}

\section{QUESTIONNAIRE}

\section{Background information:}

Name of the Interviewee:

Work title:

Start in the current role:

Previous work experience

Company:

Company Turnover:

Number of employees:

Number of employees working in NPD:

1. Which phase of the NPD chain do you represent (applied research, platform development, productisation, production, after-sales, entire chain)?

2. What type of activities do you consider as $\mathrm{V} \& \mathrm{~V}$ (or Testing,)?

3. Describe typical V\&V (Testing) activities within the phase you represent.

4. What do you expect of the previous phase?

5. What types of problems created in the previous phase/s arise here?

6. What type of actions in this phase could serve the following phase/s the best?

7. Are there any $\mathrm{V} \& \mathrm{~V}$ related bottlenecks in this phase?

8. How can the $\mathrm{V} \& \mathrm{~V}$ activities be improved in your view?

9. Other comments on $\mathrm{V} \& \mathrm{~V}$ activities

(The details of the interviewee or the company will not be disclosed in any published material.) 